\title{
Short- and long-term impacts of Acacia longifolia invasion on the belowground processes of a Mediterranean coastal dune ecosystem
}

\author{
Elizabete Marchante $^{a, b, *}$, Annelise Kjøller ${ }^{b}$, Sten Struwe ${ }^{b}$, Helena Freitas ${ }^{a}$ \\ ${ }^{a}$ Centre for Functional Ecology, Department of Botany, University of Coimbra, 3000-456 Coimbra, Portugal \\ ${ }^{b}$ Department of Microbiology, Institute of Biology, University of Copenhagen, Sølugade 83 H, DK-1307 Copenhagen K, Denmark
}

\section{A R T I C L E I N F O}

\section{Article history:}

Received 20 December 2007

Received in revised form

8 April 2008

Accepted 14 April 2008

Keywords:

Ecosystem processes

Invasive plant species

Microbial activity and biomass

Potential nitrification

Soil ecology

$\beta$-Glucosaminidase activity

\begin{abstract}
A B S T R A C T
Many coastal dune ecosystems in Portugal are invaded by the leguminous tree Acacia longifolia (Andrews) Willd. This exotic species was first introduced over one hundred years ago in an effort to mitigate dune erosion and loss of coastal landscapes. However, since then A. longifolia has spread to new areas, displacing the native vegetation. These invaded ecosystems contrast with the native dune ecosystems that are typically dominated by herb and shrub communities. This study characterizes belowground changes to the native environment as a result of recent $(<10 \mathrm{y})$ and long-term invasion ( $>20 \mathrm{y})$ by A. longifolia by analyzing a range of chemical and microbial parameters. Both invaded areas accumulated higher litter densities with greater $\mathrm{N}$ contents and lower $\mathrm{C} / \mathrm{N}$ ratios than the native areas, which corresponded to lower $\mathrm{C} / \mathrm{N}$ ratio and to higher potential rates of nitrification in the invaded soils. Long-term occupation by A. longifolia has significantly altered the soil properties with increased levels of organic $\mathrm{C}$, total $\mathrm{N}$ and exchangeable cations resulting in higher microbial biomass, basal respiration, and $\beta$-glucosaminidase activity. However, basal respiration and microbial biomass were significantly higher within recent invasion sites when calculated relative to soil organic $C$. The results from this study show that invasions by A. longifolia have altered the original native ecosystem processes and that the impacts are more pronounced within long-term invaded sites. A positive feedback mechanism is apparent for A. longifolia invading these Mediterranean dunes, which can make the restoration of native plant communities increasingly difficult with time elapsed since invasion.
\end{abstract}

(C) 2008 Elsevier B.V. All rights reserved.

\section{Introduction}

Biological invasions are a global phenomenon that frequently affect human activities and represent one of the most important drivers of biodiversity loss and ecosystem service changes (Mooney, 2005). Although invasive plants cause major changes in the composition and function of soil communities, and on soil C and nutrient dynamics (Kourtev et al., 2002;
Ehrenfeld, 2003; Yelenik et al., 2004; Wolfe and Klironomos, 2005; Bohlen, 2006), most studies on their effects have focused on aboveground flora and fauna. Since soil communities play essential roles in regulating ecosystem-level processes (Wardle et al., 2004), understanding the effects of invasive plants on soil processes is of crucial importance. Exotic plant traits such as larger size, higher growth rate and higher nutrient content than native species, the capacity to form dominant ground

* Corresponding author at: Centre for Functional Ecology, Departamento de Botânica, Universidade de Coimbra, 17 Calçada Martim de Freitas, 3000-456 Coimbra, Portugal. Tel.: +351 239855210; fax: +351 239855211.

E-mail addresses: moguita@ci.uc.pt, moguita@hotmail.com (E. Marchante). 0929-1393/\$ - see front matter (C) 2008 Elsevier B.V. All rights reserved. doi:10.1016/j.apsoil.2008.04.004 
cover or the presence of $\mathrm{N}_{2}$-fixing symbioses, may help to predict which species have higher probability to cause ecosystem-level effects (Ehrenfeld, 2004). Particularly, $\mathrm{N}_{2-}$ fixing invasive plants, such as Acacia spp. in South Africa (Yelenik et al., 2004), Myrica faia (Vitousek et al., 1987) and Falcataria moluccana (Allison et al., 2006) in Hawaii or Cytisus scoparius in California (Haubensak and Parker, 2004; Caldwell, 2006), have been shown to influence inputs of $C$ and $N$, and microbial processes, altering ecosystem-level characteristics. Several studies have specifically examined the effects of invasive Acacia spp. on nutrient cycling and mineralization (Witkowski, 1991; Stock et al., 1995; Yelenik et al., 2004) but impacts on microbial activity and biomass, nitrification or enzyme activity are poorly understood. In Portugal, ecosystem-level effects of invasion by Acacia spp. have only recently been explored (Marchante et al., 2007). Furthermore, the duration of invasion has not been considered before, although this factor has recently been recognized as an important aspect that needs to be explicitly considered in order to adequately assess the effects of many invaders (Strayer et al., 2006).

Regions under Mediterranean climate, including Portugal, are particularly vulnerable to invasions (Groves and di Castri, 1991). The expansion of alien invasive plants is threatening the Portuguese native flora and becoming a serious environmental problem (Ministério do Ambiente, 1999; Campelo, 2000; Marchante, 2001). In the Portuguese dune ecosystems, Acacia longifolia and A. saligna are among the most aggressive invasive plant species. These exotic woody legumes were planted at the beginning of the last century to curb sand erosion but have now proliferated, often associated to fire events, causing significant ecological impacts (Marchante, 2001; Marchante et al., 2003). Several Australian acacias have been used for stabilization of coastal sand dunes in different countries, and subsequently spread and invaded considerable areas, namely in South Africa (Roux, 1961) and Israel (Kutiel et al., 2004).

This study examined the impacts of A. longifolia on dune sites with different invasion histories, including recent $(<10 \mathrm{y})$ and long-term ( $>20$ y) occupation and an intact native site. We analyzed the impacts of A. longifolia invasion on soil microbial processes and on $\mathrm{C}$ and $\mathrm{N}$ pools. Considering that $\mathrm{A}$. longifolia is a legume tree, which grows faster than most native species, we hypothesize that invasion by A. longifolia promotes changes at soil chemical and microbial levels, mainly affecting properties closely related to $\mathrm{N}$-cycling. Additionally, assuming that plants established a long time ago have had more time to change the soil environment, we hypothesize that changes on soil microbial processes and pools are influenced by the duration of invasion. These studies are essential to understand the impacts of invasive plants on native ecosystems, which will help to make important management decisions related to timing and priority.

\section{Materials and methods}

\subsection{Site description}

Field experiments were conducted in the São Jacinto Dunes Nature Reserve, a coastal sand dune ecosystem of approxi- mately 660 ha, at the central-northern coast of Portugal $\left(40^{\circ} 39^{\prime} \mathrm{N}, 8^{\circ} 44^{\prime} \mathrm{W}\right)$. This dune system is habitat to several native species of herbs and shrubs adapted to this environment. The climate is Mediterranean with Atlantic influence, with a mean annual precipitation of $920 \mathrm{~mm}$ and mean monthly temperatures ranging from $10.2^{\circ} \mathrm{C}$ in January to $20.2^{\circ} \mathrm{C}$ in June. Early in the 20th century, A. longifolia (Andrews) Willd. (Sydney golden wattle) was planted for dune stabilization, and later invaded the area. In 1995, approximately $1 / 3$ of the vegetation in the reserve burned in a natural fire and this area was rapidly invaded by $A$. longifolia. The fire has most likely changed the system (see Section 4). At present, approximately $2 / 3$ of the reserve is occupied by $A$. longifolia. The indigenous vegetation has been mostly replaced by arboreal stands of A. longifolia (Marchante, 2001; Marchante et al., 2003). Prior to invasion, the area was presumably vegetated as the non-invaded areas are at present.

\subsection{Experimental design}

Three types of areas in the Reserve were compared: one invaded by A. longifolia for a long time (LI), one recently invaded (RI), and an area with an intact native plant community, noninvaded (NI). In LI, A. longifolia invaded several decades ago; although its control was attempted, reinvasion occurred and the area has been densely vegetated by A. longifolia for more than 20 years. In RI, A. longifolia invaded after the fire in 1995; before this, only a few scattered A. longifolia individuals were present in these areas. Nowadays, A. longifolia is the dominant species in both types of invaded areas, forming closed stands (frequently cover $>90 \%$ ) with none or few native species occupying the understory.

Thirteen $10 \mathrm{~m} \times 10 \mathrm{~m}$ plots were established in the Reserve: five in LI areas, five in RI areas, and three in NI areas. Due to the Reserve characteristics and A. longifolia distribution, it was not possible to use a randomized block design. Therefore, plots were randomly distributed in areas with similar elevation, distance from the ocean and potential vegetation. The sample sites were at least $100 \mathrm{~m}$ inland of the primary dune system in a zone where sediments are stable and sand mobility is low. Soils are arenosols (FAO classification) (Rogado et al., 1993).

\subsection{Soil and litter sampling}

Three soil samples were collected in every $10 \mathrm{~m} \times 10 \mathrm{~m}$ replicate plot (15 samples in $\mathrm{LI}$ and $\mathrm{RI}$, and 9 in NI), in the spring of 2004, 2005 and 2006. Each sample was composed of two sub-samples (collected 1-2 m apart) taken to a depth of $10 \mathrm{~cm}$ with an $8 \mathrm{~cm}$ diameter soil corer; the litter layer was discarded. Bulk soil was sampled to evaluate effects of invasion on soil as a whole. Samples were passed through a $4 \mathrm{~mm}$ sieve to remove coarse roots and organic debris. Soil for microbial analyses was kept at $4{ }^{\circ} \mathrm{C}$ until analysis. Mineral $\mathrm{N}$ and water content were analyzed on fresh soil while other chemical analyses were made on air-dried soil. In each plot, three litter samples, corresponding to the litter accumulated on an area of $50 \mathrm{~cm}^{2}$, were collected, air-dried and stored for later processing. 


\subsection{Soil and litter analysis}

\subsubsection{Chemical analysis}

Soils were analyzed for Kjeldahl N (Bremner, 1965), organic C (Tinsley method, adapted by Silva, 1977), $\mathrm{NH}_{4}{ }^{+}$and $\mathrm{NO}_{3}{ }^{-}$ (extracted with $0.1 \mathrm{M} \mathrm{CaCl}_{2}$ and analyzed with an autoanalyzer), available $\mathrm{P}$ (extracted with $0.5 \mathrm{M} \mathrm{NaHCO}_{3}$ and analyzed colorimetrically with the ascorbic acid molybdate method, Olsen and Sommer, 1982), $\mathrm{pH}\left(\mathrm{H}_{2} \mathrm{O}, \mathrm{Mc}\right.$ Lean, 1982), soil cations $\left(\mathrm{Ca}^{2+}, \mathrm{Na}^{+}, \mathrm{K}^{+}\right.$and $\mathrm{Mg}^{2+}$, extracted with $\mathrm{NH}_{4} \mathrm{C}_{2} \mathrm{H}_{3} \mathrm{O}_{2}$ and analyzed on atomic absorption spectrophotometer with flame atomizer (PerkinElmer Analyst 100), Heinrichs et al., 1996), and soil gravimetric water (oven dried at $105^{\circ} \mathrm{C}$ for $48 \mathrm{~h}$ ). Litter was oven dried at $60^{\circ} \mathrm{C}$ for $48 \mathrm{~h}$ and $\mathrm{N}$ analyzed as for soil samples. Litter $\mathrm{C}$ was analyzed by drying the litter for $24 \mathrm{~h}$ at $105^{\circ} \mathrm{C}$ followed by calculating loss on ignition in a furnace at $450{ }^{\circ} \mathrm{C}$ for $6 \mathrm{~h}$.

\subsubsection{Basal respiration and microbial biomass $C$}

Basal respiration was used as a measure of overall soil microbial activity, and C mineralization (Rey et al., 2005). Soil microbial biomass $C$ was determined via substrate-induced respiration (SIR) to provide a measure of the total, physiologically active part of the microflora (Anderson and Domsch, 1978). For SIR, $1 \mathrm{~g}$ field moist soil was weighted into $20 \mathrm{ml}$ serum bottles, $50 \mu \mathrm{l}$ water was added, and kept overnight for acclimation. The following day, $2 \mathrm{mg}$ glucose $\mathrm{g}^{-1}$ field moist soil $(50 \mu \mathrm{l})$ was added to each sample. Water and glucose solution were added to achieve $60 \%$ of water holding capacity. Bottles were capped airtight and incubated at room temperature. After $4 \mathrm{~h}, 0.5 \mathrm{ml}$ gas from the headspace was sampled with a syringe and $\mathrm{CO}_{2}$ measured in a gas chromatograph equipped with a TC detector (TCD $180^{\circ} \mathrm{C}$, carrier gas He, column GS-CPLOT, oven $90^{\circ} \mathrm{C}$, average velocity: $100 \mathrm{~cm} \mathrm{~s}^{-1}$ ). Basal respiration was measured in the same way as SIR but water was added instead of glucose solution and $\mathrm{CO}_{2}$ was measured after $24 \mathrm{~h}$ incubation.

The percentage of microbial biomass $C$ in soil organic $C$ (Cmic:Corg) was calculated.

\subsection{3. $\quad \beta$-Glucosaminidase activity}

4-MUF N-acetyl- $\beta$-D-glucosaminide (Sigma Chemical Co.) was used as substrate to quantify $N$-acetyl- $\beta$-D-glucosaminidase (EC 3.2.1.30, hereafter $\beta$-glucosaminidase). $\beta$-Glucosaminidase is an enzyme involved in chitin degradation in soil. Chitin is one of the most abundant biopolymers on earth, serving as an important transient pool of organic $\mathrm{C}$ and $\mathrm{N}$ in soil (Ekenler and Tabatabai, 2003). $\beta$-Glucosaminidase has been used as a measure of N-mineralization (Ekenler and Tabatabai, 2004) and fungal biomass (Miller et al., 1998). The protocol used has been described by Miller et al. (1998) and later modified by Andersson et al. (2004).

\subsubsection{Potential nitrification}

Nitrification was assayed as a key sensitive process in $\mathrm{N}$ cycling. Ten grams of field moist soil were added to $100 \mathrm{ml}$ nutrient solution $\left(5 \mathrm{mM} \quad \mathrm{NaCl}, 1 \mathrm{mM} \quad \mathrm{KH}_{2} \mathrm{PO}_{4}, 1 \mathrm{mM}\right.$ $\mathrm{MgSO}_{4} \cdot 7 \mathrm{H}_{2} \mathrm{O}$ and $\left.1 \mathrm{gl}^{-1} \mathrm{CaCO}_{3}, \mathrm{pH} 7.2\right)$, supplied with $5 \mathrm{mM}$ $\left(\mathrm{NH}_{4}\right)_{2} \mathrm{SO}_{4}$ and incubated at $25^{\circ} \mathrm{C}$ (adapted from Aaronson, 1970). After 14 days, sub-samples were collected and $\mathrm{NO}_{3}{ }^{-}$ extracted with $1 \mathrm{M} \mathrm{KCl}$, followed by centrifugation for $15 \mathrm{~min}$ at $3500 \mathrm{rpm}$; the supernatant obtained was filtered through an $\mathrm{N}$-free filter. $\mathrm{NO}_{3}{ }^{-}$was determined on an Aquatec analyzer by measuring $\mathrm{NO}_{2}{ }^{-}$and $\mathrm{NO}_{3}{ }^{-}+\mathrm{NO}_{2}{ }^{-}$, and calculating the amount of $\mathrm{NO}_{3}{ }^{-}$. Potential nitrification was calculated as $\mu \mathrm{g} \mathrm{NO}_{3}-\mathrm{N} \mathrm{g}^{-1}$ dry soil day ${ }^{-1}$.

All results were expressed per $g$ of dry soil, and microbial biomass $C$, basal respiration, and $\beta$-glucosaminidase activity, which are linked to the decomposition of organic material, were also calculated per $g$ of organic $C$. The results are shown in both units to better explain the conclusions.

\subsection{Statistical analyses}

Results from the three sub-samples from each replicate plot were pooled to avoid pseudoreplication. We used a 2-way ANOVA to test for the effects of invasion and sampling date on soil microbiological and chemical properties. If sampling date or its interaction was significant in the 2-way ANOVA, we presented and analyzed the data from different years separately using a 1-way ANOVA with invasion as main effect. If there was no significant effect of sampling date, we ran a 1-way ANOVA on pooled data from 2004, 2005 and 2006. Mean differences were separated with Tukey's HSD test at 5\% level of significance. When necessary, data were log-transformed in order to accomplish the homogeneity assumption of ANOVA. STATISTICA 6.0 (StatSoft, Inc., 2001, www.statsoft.com) was used for the statistical analysis.

\section{Results}

\subsection{Litter analysis}

The quantity of litter accumulated on the soil surface (Table 1) was 3.4- and 2.4-fold greater in areas long and recently invaded by A. longifolia than in non-invaded sites, respectively. The percentage of $\mathrm{C}$ in litter was higher in long-term invaded and non-invaded than in recently invaded areas. The amount of $\mathrm{C}$ accumulated in litter was significantly higher in both invaded areas, compared to non-invaded sites, with long invaded areas accumulating as much as 3.5 times more litter C than non-invaded and 1.5 more than recently invaded areas.

Table 1 - Quantity and chemical properties of litter collected in LI, RI and NI areas in the São Jacinto Dunes Nature Reserve

\begin{tabular}{lccc} 
& LI & RI & NI \\
\hline Litter $\left(\mathrm{kg} \mathrm{m}^{-2}\right)$ & $2.05(0.24)^{\mathrm{a}}$ & $1.43(0.14)^{\mathrm{b}}$ & $0.60(0.06)^{\mathrm{c}}$ \\
$\mathrm{C}(\%)$ & $52.3(0.43)^{\mathrm{a}}$ & $49.53(0.46)^{\mathrm{b}}$ & $53.6(0.60)^{\mathrm{a}}$ \\
$\mathrm{C}\left(\mathrm{kg} \mathrm{m}^{-2}\right)$ & $1.12(0.10)^{\mathrm{a}}$ & $0.73(0.08)^{\mathrm{b}}$ & $0.32(0.04)^{\mathrm{c}}$ \\
$\mathrm{N}(\%)$ & $1.71(0.08)^{\mathrm{a}}$ & $1.79(0.08)^{\mathrm{a}}$ & $1.13(0.17)^{\mathrm{b}}$ \\
$\mathrm{N}\left(\mathrm{g} \mathrm{m}^{-2}\right)$ & $34.8(5.90)^{\mathrm{a}}$ & $26.7(3.5)^{\mathrm{a}}$ & $6.48(0.56)^{\mathrm{b}}$ \\
$\mathrm{C} / \mathrm{N}$ & $31(3.47)^{\mathrm{b}}$ & $28(2.31)^{\mathrm{b}}$ & $50(14.5)^{\mathrm{a}}$
\end{tabular}

Values are means (S.E.), $n=5$ for LI and RI, $n=3$ for NI. Values in the row with the same letter $(\mathrm{a}-\mathrm{c})$ are not significantly different (Tukey test, $\mathrm{P}<0.05$ ). LI-areas invaded by A. longifolia for $>20 \mathrm{y}$; RI-areas invaded by A. longifolia $<10$ y; NI-areas non-invaded by A. longifolia. 
Table 2 - Chemical properties in the upper $10 \mathrm{~cm}$ of soil collected in LI, RI and NI areas in the São Jacinto Dunes Nature Reserve

\begin{tabular}{|c|c|c|c|c|}
\hline Soil property & Year & LI & RI & NI \\
\hline C $(\%)$ & $2004 / 2006$ & $2.09(0.23)^{c}$ & $0.58(0.04)^{\mathrm{a}}$ & $1.11(0.15)^{b}$ \\
\hline Kjeldahl N (\%) & $2004 / 2006$ & $0.12(0.011)^{\mathrm{b}}$ & $0.04(0.004)^{a}$ & $0.06(0.014)^{\mathrm{a}}$ \\
\hline $\mathrm{C} / \mathrm{N}$ & $2004 / 2006$ & $17(0.8)^{\mathrm{b}}$ & $13(0.4)^{a}$ & $22(2.1)^{c}$ \\
\hline $\mathrm{NH}_{4}{ }^{+}-\mathrm{N}\left(\mu \mathrm{g} \mathrm{g}^{-1}\right)$ & $2004 / 2005$ & $2.46(0.34)^{\mathrm{b}}$ & $0.75(0.21)^{\mathrm{a}}$ & $1.60(0.47)^{\mathrm{ab}}$ \\
\hline \multirow[t]{2}{*}{$\mathrm{NO}_{3}{ }^{-}-\mathrm{N}\left(\mu \mathrm{g} \mathrm{g}^{-1}\right)$} & 2004 & $1.45(0.26)^{a}$ & $1.96(0.47)^{\mathrm{a}}$ & $1.80(0.47)^{\mathrm{a}}$ \\
\hline & 2005 & $0.37(0.07)^{\mathrm{a}}$ & $0.30(0.08)^{\mathrm{a}}$ & $0.67(0.62)^{a}$ \\
\hline \multirow[t]{2}{*}{$\mathrm{P}\left(\mu \mathrm{g} \mathrm{g}^{-1}\right)$} & 2004 & $1.44(0.22)^{\mathrm{a}}$ & $1.64(0.24)^{\mathrm{a}}$ & $1.31(0.16)^{\mathrm{a}}$ \\
\hline & 2005 & $0.64(0.12)^{a}$ & $0.58(0.08)^{a}$ & $0.69(0.06)^{a}$ \\
\hline \multirow[t]{2}{*}{$\mathrm{pH}\left(\mathrm{H}_{2} \mathrm{O}\right)$} & 2004 & $4.43(0.08)^{a}$ & $5.11(0.22)^{\mathrm{b}}$ & $4.81(0.12)^{\mathrm{ab}}$ \\
\hline & 2005 & $4.08(0.05)^{\mathrm{a}}$ & $4.15(0.04)^{\mathrm{a}}$ & $4.30(0.10)^{\mathrm{a}}$ \\
\hline \multirow[t]{2}{*}{$\mathrm{H}_{2} \mathrm{O}$ content $(\%)$} & 2004 & $8.02(0.72)^{b}$ & $1.82(0.40)^{\mathrm{a}}$ & $2.94(0.63)^{\mathrm{a}}$ \\
\hline & 2005 & $10.3(0.73)^{\mathrm{b}}$ & $4.93(0.10)^{\mathrm{a}}$ & $5.70(1.32)^{\mathrm{a}}$ \\
\hline $\mathrm{Ca}^{2+}\left(\mu \mathrm{g} \mathrm{g}^{-1}\right)$ & $2004 / 2005$ & $672(121.9)^{b}$ & $324(66.9)^{a}$ & $279(52.1)^{\mathrm{a}}$ \\
\hline $\mathrm{Na}^{+}\left(\mu \mathrm{gg}^{-1}\right)$ & $2004 / 2005$ & $22.0(5.06)^{b}$ & $8.69(0.85)^{\mathrm{a}}$ & $6.70(1.56)^{a}$ \\
\hline $\mathrm{K}^{+}\left(\mu \mathrm{g} \mathrm{g}^{-1}\right)$ & $2004 / 2005$ & $23.7(4.06)^{b}$ & $11.1(0.65)^{a}$ & $11.7(0.99)^{\mathrm{a}}$ \\
\hline $\mathrm{Mg}^{2+}\left(\mu \mathrm{gg}^{-1}\right)$ & $2004 / 2005$ & $72.4(9.18)^{b}$ & $32.8(3.09)^{\mathrm{a}}$ & $43.0(4.56)^{\mathrm{a}}$ \\
\hline
\end{tabular}

Values are means (S.E.), $n=5$ for LI and RI, $n=3$ for NI. When results from different years were similar, results were pooled; otherwise, values from each year are shown separately. Values in the row with the same letter $(a-c)$ are not significantly different $($ Tukey test, $P<0.05)$. Abbreviations as for Table 1.

The percentage of $\mathrm{N}$ in litter (Table 1 ) was more than 1.5fold higher in areas invaded by A. longifolia than in areas with native species. Both the higher quantity of litter and the higher $\mathrm{N}$ content were reflected in an approximately 5 -fold increase in $\mathrm{N}$ accumulated in litter on the invaded areas, compared to the native sites. The $\mathrm{C} / \mathrm{N}$ ratio was highest in litter from native communities.

\subsection{Soil chemical analyses}

Organic C content (Table 2) was significantly higher in long invaded areas than in the other two types of areas. Areas invaded after 1995 showed the lowest organic C content. After a long period of invasion, the organic $C$ content increased more than $70 \%$, compared to non-invaded areas. Soil total $\mathrm{N}$ was on average 2.6 times higher in long invaded than in recently invaded and native areas. The $\mathrm{C} / \mathrm{N}$ ratio was higher in noninvaded areas than in areas invaded by A. longifolia, independently of the time since invasion. Long invaded areas showed a $\mathrm{C} / \mathrm{N}$ ratio higher than those that were recently invaded.

$\mathrm{NH}_{4}{ }^{+}$was almost 3 times lower in recently invaded than in long invaded areas. Native sites showed $\mathrm{NH}_{4}{ }^{+}$contents similar both to recently and long invaded soils. There were no significant differences in $\mathrm{NO}_{3}{ }^{-}$content between areas, neither in 2004, or 2005.

Phosphorus concentrations (Table 2) revealed no significant differences between areas in both sampling years. pH was significantly higher in recently invaded than in long invaded areas only in 2004. Soil water content was up to twice as high in long invaded as in recently invaded and native areas. Twoto 3-fold higher concentrations of the cations $\mathrm{Ca}^{2+}, \mathrm{Na}^{+}, \mathrm{K}^{+}$and $\mathrm{Mg}^{2+}$ were found in long invaded areas, as compared to recently invaded and non-invaded areas.

\subsection{Soil microbiological analyses}

On a dry soil basis, basal respiration, microbial biomass $C$ and $\beta$-glucosaminidase activity (Fig. 1) were significantly higher in long invaded areas than in the two other types. Basal respiration and microbial biomass $C$ were both approximately 1.5-fold higher and $\beta$-glucosaminidase activity was about 3fold higher in long invaded than in recently invaded and noninvaded areas.

The invasion by A. longifolia promoted a significant increase of potential nitrification (Fig. 1), independently of the time since invasion. The $\mathrm{NO}_{3}{ }^{-}$production was 48-285 times higher in invaded areas than in non-invaded.

When basal respiration, microbial biomass $C$ and $\beta$ glucosaminidase activity were calculated relative to organic C (Fig. 2), the results were different from the ones on a dry soil basis. In 2004 and 2005, basal respiration and microbial biomass $\mathrm{C}$ were similar in long invaded and non-invaded areas, and significantly higher in recently invaded sites. In 2006, however, non-invaded areas showed intermediate values, similar to both recently and long invaded areas. $\beta$ Glucosaminidase activity was 2.3 and 2.9 times higher in long and recently invaded areas, respectively, than in soil from native communities.

In 2004 and 2005, the percentage of microbial biomass C relative to the organic $\mathrm{C}$ (Cmic:Corg) was higher in recently invaded areas (4.2-4.8\%), approximately twice the value for long invaded and non-invaded areas (2.0-2.6\%). In 2006 Cmic:Corg ratio was also higher in recently invaded (5.6\%), but intermediate in non-invaded (4.4\%) and lower in long invaded soil (2.4\%).

\section{Discussion}

\subsection{Effects of A. longifolia invasion on soil chemical and microbial properties}

As hypothesized, results show that invasion by A. longifolia changes soil nutrient pools and processes. The pools and processes related to $\mathrm{N}$ cycling were the most affected, but $\mathrm{C}$ cycling dynamics were also substantially altered. This is not 

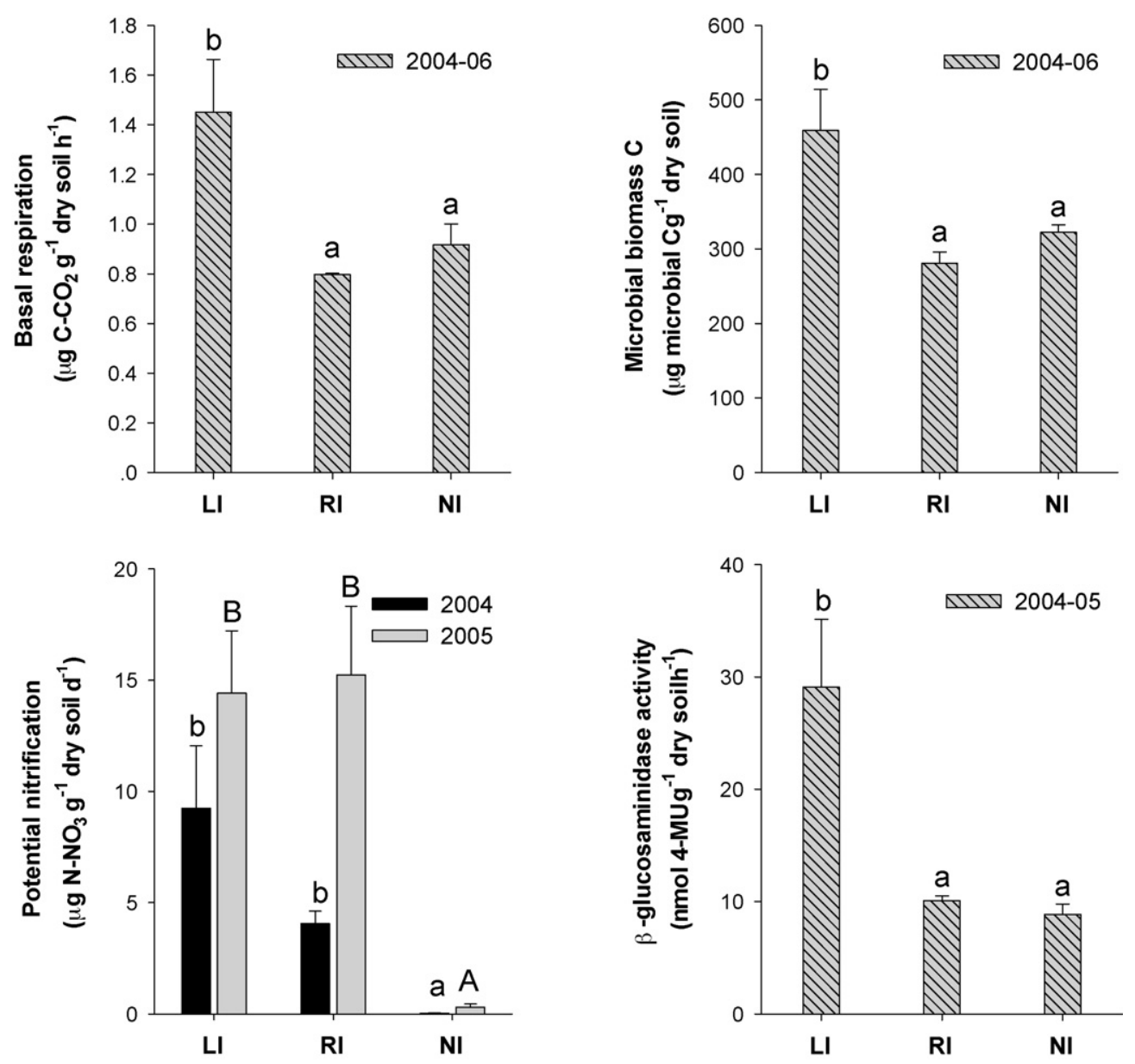

Fig. 1 - Basal respiration, microbial biomass C, potential nitrification and $\beta$-glucosaminidase activity on dry soil basis, in the upper $10 \mathrm{~cm}$ of soil collected in LI, RI and NI areas in the São Jacinto Dunes Nature Reserve. Bars are means + S.E., $n=5$ for LI and RI, $n=3$ for NI. When results from different years were similar, results were pooled; otherwise, values from each year are shown separately. Bars with the same letter are not significantly different (Tukey test, $P<0.05)$. Abbreviations as for Table 1 .

surprising considering that the native dune system with low productivity shrubs and herbs is now dominated by a highly productive $\mathrm{N}_{2}$-fixing tree. Acacia longifolia produces copious amounts of litter with higher $\mathrm{N}$ content, and lower $\mathrm{C} / \mathrm{N}$ ratio, which leads to higher nutrient and $\mathrm{C}$ content and thus to increased microbial activities in the invaded soil. Several invasive $\mathrm{N}_{2}$-fixing species increase the litter inputs with higher $\mathrm{N}$ content and faster decomposition, resulting in more
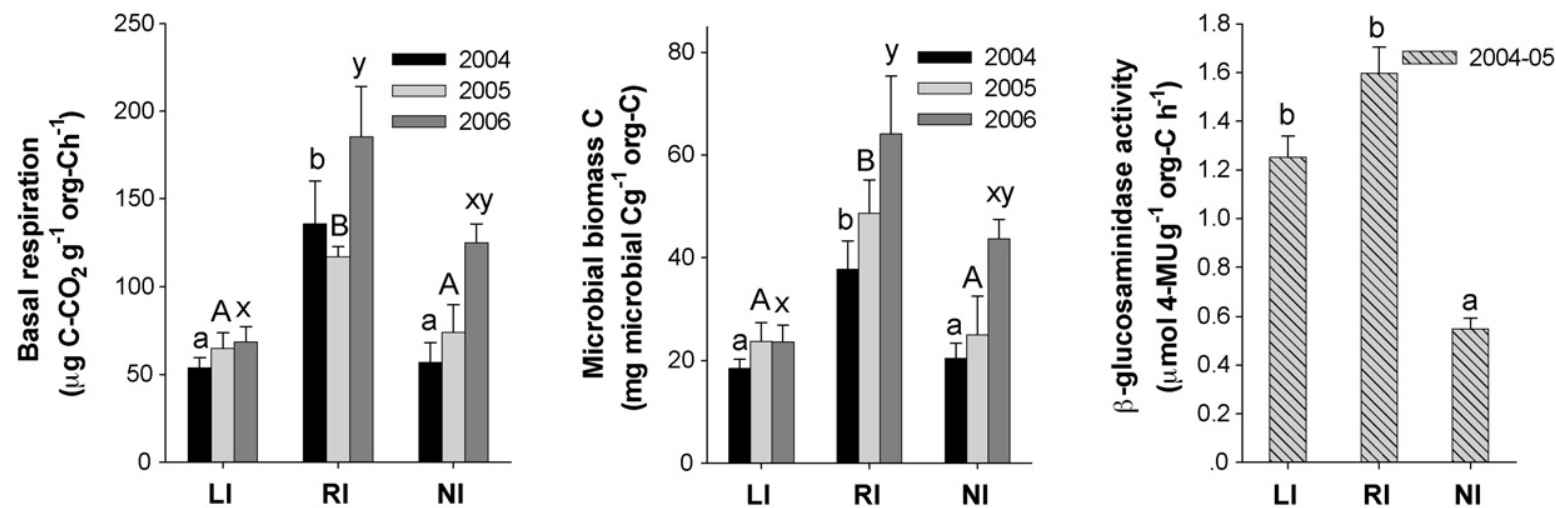

Fig. 2 - Basal respiration, microbial biomass $C$, and $\beta$-glucosaminidase activity on organic $C$ basis, in the upper $10 \mathrm{~cm}$ soil collected in LI, RI and NI areas in the São Jacinto Dunes Nature Reserve. Bars are means + S.E., $n=5$ for LI and RI, $n=3$ for NI. When results from different years were similar, results were pooled; otherwise, values from each year are shown separately. Bars with the same letter are not significantly different (Tukey test, $P<0.05$ ). Abbreviations as for Table 1 . 
$\mathrm{N}$ returning from the aboveground biomass to the soil (Witkowski, 1991; Yelenik et al., 2004; Hughes and Denslow, 2005; Allison et al., 2006). These effects may be driven by $\mathrm{N}$ fixation or more efficient $\mathrm{N}$ uptake as suggested for different Acacia species (Witkowski, 1991).

In the present study, the amount of $\mathrm{C}$ and $\mathrm{N}$ accumulated in litter is higher in both invaded sites, but only reflected in pools of $C$ and nutrients in long invaded soil, possibly due to the prolonged presence of A. longifolia. The increase in soil and litter $\mathrm{N}$, nitrification and $\beta$-glucosaminidase activity indicate that invasion by $\mathrm{A}$. longifolia is changing $\mathrm{N}$ pools (in long invaded) and $\mathrm{N}$ availability (in long and recently invaded areas). In some South African sites, $\mathrm{N}$ availability increased after invasion by Acacia spp. (Stock et al., 1995; Yelenik et al., 2004), even in early stages of invasion (Witkowski, 1991) while in others it did not (Witkowski, 1991; Stock et al., 1995). The different effects were attributed to differences in the leaf chemistry of Acacia spp. or in the soil properties and processes associated with the different systems (Stock et al., 1995).

In soil of recent and long invaded areas, potential nitrification showed striking increases, possibly reflecting $\mathrm{N}$ inputs through litter or $\mathrm{N}$-fixation. Promotion of nitrification may be a mechanism of self-facilitation in A. longifolia; an effective nutrient uptake and the ability to use $\mathrm{NH}_{4}{ }^{+}$and $\mathrm{NO}_{3}{ }^{-}$ equally well have been reported as competitive advantages of this species (Peperkorn, 2005). In our study, the $\mathrm{NO}_{3}{ }^{-}$pool was not higher in the invaded sites as $\mathrm{NO}_{3}{ }^{-}$is easily used by plants, immobilized in microorganisms, or leached. The small $\mathrm{NH}_{4}{ }^{+}$ pool in the recently invaded areas corresponds well with the total $\mathrm{N}$ content, which is lower than in the long invaded, and may reflect higher plant uptake and increased nitrification than in non-invaded sites. The activity of the enzyme $\beta$ glucosaminidase, which has been proposed as an index of $\mathrm{N}$ mineralization (Ekenler and Tabatabai, 2004), also increased significantly in the invaded areas, although it was expected to decrease with higher $\mathrm{N}$ availability (Sinsabaugh and Moorhead, 1994; Allison et al., 2006). The higher amount of litter in invaded areas seemed to be more significant than mineral $\mathrm{N}$ availability in regulating enzyme production. A similar situation has been reported after invasion by Falcataria in Hawaii, where litter input and $\mathrm{C}$ and $\mathrm{N}$ pools increased in invaded areas, supporting microbial growth and enzyme activity (Allison et al., 2006).

Results show that in the study site A. longifolia invades areas with low nutrient content and subsequently enriches the soil, rather than invading only rich soils. This agrees with recent findings by Funk and Vitousek (2007) which show that plants do invade low-resource systems, and not preferentially high resource availability sites, as previously thought.

\subsection{Time since invasion}

The effects of A. longifolia differed in the two types of invaded areas. Measurements of litter accumulation and nitrification activity demonstrate that areas occupied by A. longifolia for $<10$ y have already altered soil processes and pools. However, most of the measured microbial processes on dry soil basis and nutrient levels were higher in long invaded than in the recently invaded areas, demonstrating that changes in ecosystem processes are more profound after a long time of invasion. Organic C content was unexpectedly lower in recently invaded areas than in native areas. We initially assumed that although the fire in 1995 could have reduced $C$ content, the $\mathrm{C}$ and nutrient pools would have reached the prefire levels after 10 years, as observed by Dumontet et al. (1996) in a Mediterranean dune pine forest. However, in our study system, the $\mathrm{C}$ pool in the burned plots was still lower than in the non-invaded plot. C content may decrease after one fire event (Carreira et al., 1994), while soil total $\mathrm{N}$ is not significantly influenced by fire (Wan et al., 2001) or decreases only after a sequence of fire events (Carreira et al., 1994; Haubensak and Parker, 2004). Musil and Midgley (1990) studied the effects of A. saligna invasion and of fire on soil chemical status of South African fynbos and concluded that the impact of the invader was greater than that of fire. The effects of $A$. longifolia invasion on $\mathrm{C}$ and $\mathrm{N}$ were therefore expected to be more important than the effects of burning 10 years before. However, the high $\mathrm{C}$ and $\mathrm{N}$ inputs from litter in recently invaded areas (Table 1) have not yet been recorded in the soil, suggesting that it takes a long time before $\mathrm{C}$ and $\mathrm{N}$ accumulate. We propose that the $\mathrm{C}$ content has decreased with the fire in 1995, and possibly $\mathrm{N}$ to a lesser extent, and both $\mathrm{C}$ and $\mathrm{N}$ pools have since been slowly increasing as a result of invasion. The same size of microbial biomass $C$ in recently and non-invaded areas (contrary to lower soil $\mathrm{C}$ in recently than in non-invaded areas) and increased nitrification may be seen as early indicators of $\mathrm{C}$ and $\mathrm{N}$ accumulation.

When results were calculated relative to organic $\mathrm{C}$, a different view was obtained. Higher basal respiration and Cmic:Corg in recently invaded areas suggest more intensive $C$ mineralization than in long invaded soil. The difference in $\mathrm{C} / \mathrm{N}$ ratio between recently and long invaded soils may reflect qualitative differences of soil organic matter (SOM) which could explain the different activity levels. In these invaded plots, SOM will slowly accumulate based on the balance between litter input and mineralization. In long invaded sites, SOM has been building up for a longer period, resulting in a higher $\mathrm{C}$ content, with a fraction of this possibly being recalcitrant. In many soils, a large proportion of organic $C$ is recalcitrant and therefore the different fractions of organic $\mathrm{C}$ may be more important for microbial degradation than the total amount (Wardle, 1992). McCulley et al. (2004) observed an increase in fluxes and pools of $\mathrm{C}$ and $\mathrm{N}$ and a decrease of Cmic:Corg when grasslands were replaced by woody communities, and attributed these effects to a larger increase in the recalcitrant pool of organic $C$ than in the labile pool.

Depending on the species, life form and system invaded, the effects of $\mathrm{N}_{2}$-fixing invasive species can be different (Stock et al., 1995; Yelenik et al., 2007). $\mathrm{N}_{2}$-fixing woody (Acacia) and herb (Lupinus) species both increased available $\mathrm{N}$ while only the Acacia increased total N (Yelenik et al., 2007). However, these effects attributed to different life forms are observed in areas invaded by A. longifolia at different times, stressing the importance of these findings.

\section{Conclusions}

Invasion by A. longifolia is changing ecosystem processes in the São Jacinto Dunes Nature Reserve, a Mediterranean coastal 
dune ecosystem. Our results support other studies that show an increase in $\mathrm{N}$ cycling dynamics and $\mathrm{C}$ accumulation following invasion by $\mathrm{N}_{2}$-fixing woody plants. We further document effects on microbial biomass $C$ and microbial activity, and show that the impacts of the invasive A. longifolia in soil are influenced by time since invasion. Even with high litter inputs, soil $\mathrm{C}$ and $\mathrm{N}$ accumulation takes time, and therefore areas recently invaded are more likely to achieve a successful restoration. Soil changes may generate a positivefeedback that favours the invasive species and complicate restoration. Further studies are being conducted in order to clarify whether high nutrient levels in the soil may be problematic for the restoration of native plants adapted to poor sandy substrates. We also want to understand whether changes at soil chemical and microbial levels are permanent or if they may be reversed through the sustainable management of A. longifolia.

\section{Acknowledgements}

Special thanks to Hélia Marchante, John Hoffmann, Sofia Costa and one anonymous reviewer for valuable comments on the manuscript and checking of English grammar. We are also grateful to Karin Vestberg for technical assistance and Carla Santos for cations, $\mathrm{pH}$, and $\mathrm{P}$ analysis. This research was supported by FCT-MCTES (Portuguese Foundation for Science and Technology) and European fund FEDER, project POCTI/ BSE/42335/2001 and POCI/AMB/61387/2004. E.M. was supported by a FCT-MCTES grant.

\section{R E F E R E N C E S}

Aaronson, S., 1970. Experimental Microbial Ecology. Academic Press, New York, 236 pp.

Allison, S.D., Nielsen, C., Hughes, R., 2006. Elevated enzyme activities in soils under the invasive nitrogen-fixing tree Falcataria moluccana. Soil Biol. Biochem. 38, 1537-1544.

Anderson, J.P.E., Domsch, K.H., 1978. A physiological method for the quantitative measurement of microbial biomass in soils. Soil Biol. Biochem. 10, 215-221.

Andersson, M., Kjøller, A., Struwe, S., 2004. Microbial enzyme activities in leaf litter, humus and mineral soil layers of European forests. Soil Biol. Biochem. 36, 1527-1537.

Bohlen, P.J., 2006. Biological invasions: linking the aboveground and belowground consequences. Appl. Soil Ecol. 32, 1-5.

Bremner, J.M., 1965. Total nitrogen. In: Black, C.A. (Ed.), Methods of Soil Analysis. Part 2. Chemical and Microbiological Properties. American Society of Agronomy, Inc., Madison, USA, pp. 1149-1176.

Caldwell, B.A., 2006. Effects of invasive scotch broom on soil properties in a Pacific coastal prairie soil. Appl. Soil Ecol. 32, 149-152.

Campelo, F., 2000. Estudo da invasão dos ecossistemas dunares portugueses por Carpobrotus edulis. Master Thesis. Faculty of Sciences and Technology, University of Coimbra, Coimbra.

Carreira, J.A., Niell, F.X., Lajtha, K., 1994. Soil-nitrogen availability and nitrification in Mediterranean shrublands of varying fire history and successional stage. Biogeochemistry 26, 189-209.

Dumontet, S., Dinel, H., Scopa, A., Mazzatura, A., Saracino, A., 1996. Post-fire soil microbial biomass and nutrient content of a pine forest soil from a dunal Mediterranean environment. Soil Biol. Biochem. 28, 1467-1475.

Ehrenfeld, J.G., 2003. Effects of exotic plant invasions on soil nutrient cycling processes. Ecosystems 6, 503-523.

Ehrenfeld, J.G., 2004. Implications of invasive species for belowground community and nutrient processes. Weed Technol. 18, 1232-1235.

Ekenler, M., Tabatabai, M.A., 2003. Tillage and residue management effects on $\beta$-glucosaminidase activity in soils. Soil Biol. Biochem. 35, 871-874.

Ekenler, M., Tabatabai, M.A., 2004. $\beta$-Glucosaminidase activity as an index of nitrogen mineralization in soils. Commun. Soil Sci. Plan. 35, 1081-1094.

Funk, J.L., Vitousek, P.M., 2007. Resource-use efficiency and plant invasion in low-resource systems. Nature 446 , 1079-1081.

Groves, R.H., di Castri, K.J., 1991. Biogeography of Mediterranean Invasions. Cambridge University Press, Cambridge, $501 \mathrm{pp}$.

Haubensak, K.A., Parker, I.M., 2004. Soil changes accompanying invasion of the exotic shrub Cytisus scoparius in glacial outwash prairies of western Washington [USA]. Plant Ecol. 175, 71-79.

Heinrichs, H., Brumsack, H.J., Loftfield, N., König, N., 1996. Verbessertes Druckaufschlußsystem für Biologische und Anorganische Materialen. Z. Pflanzenernähr. Bodenk 149, 350-355.

Hughes, R.F., Denslow, J.S., 2005. Invasion by a $\mathrm{N}_{2}$-fixing tree alters function and structure in wet lowland forests of Hawaii. Ecol. Appl. 15, 1615-1628.

Kourtev, P.S., Ehrenfeld, J.G., Häggblom, M., 2002. Exotic plant species alter the microbial community structure and function in the soil. Ecology 83, 3152-3166.

Kutiel, P., Cohen, O., Shoshany, M., Shub, M., 2004. Vegetation establishment on the southern Israeli coastal sand dunes between the years 1965 and 1999. Landscape Urban Plann. 67, 141-156.

Marchante, E., Kjøller, A., Struwe, S., Freitas, H., 2007. Soil microbial activity in dune ecosystems in Portugal invaded by Acacia longifolia. In: Tokarska-Guzik, B., Brock, J.H., Brundu, G., Child, L., Daehler, C.C., Pyšek, P. (Eds.), Plant Invasions: Human Perception, Ecological Impacts and Management. Backhuys Publishers, Leiden, The Netherlands, pp. 247-257.

Marchante, H., 2001. Invasão dos ecossistemas dunares portugueses por Acacia: uma ameaça para a biodiversidade nativa. Master Thesis. Faculty of Sciences and Technology, University of Coimbra, Coimbra.

Marchante, H., Marchante, E., Freitas, H., 2003. Invasion of the Portuguese dune ecosystems by the exotic species Acacia longifolia (Andrews) Willd.: effects at the community level. In: Child, L.E., Brock, J.H., Brundu, G., Prach, K., Pyšek, P., Wade, P.M., Williamson, M. (Eds.), Plant Invasion: Ecological Threats and Management Solutions. Backhuys Publishers, Leiden, The Netherlands, pp. 75-85.

Mc Lean, E.O., 1982. Soil pH and lime requirement. In: Page, A.L., Miller, R.H., Keeney, D.R. (Eds.), Methods of Soil Analysis. Part 2. Chemical and Microbiological Properties. American Society of Agronomy, Inc., Madison, Wisconsin, USA, pp. 199-209.

McCulley, R.L., Archer, S.R., Boutton, T.W., Hons, F.M., Zuberer, D.A., 2004. Soil respiration and nutrient cycling in wooded communities developing in grassland. Ecology 85, 28042817.

Miller, M., Palojarvi, A., Rangger, A., Reeslev, M., Kjoller, A., 1998. The use of fluorogenic substrates to measure fungal presence and activity in soil. Appl. Environ. Microbiol. 64, 613-617. 
Ministério do Ambiente, 1999. Decreto-lei n. ${ }^{\circ}$ 65/99 de 21 de Dezembro. In: Diário da República - I Série - A, 295, pp. 9100 9114.

Mooney, H.A., 2005. Invasive alien species: the nature of the problem. In: Mooney, H.A., Mack, R.N., McNeely, J.A., Neville, L.E., Schei, P.J., Waage, J.K. (Eds.), Invasive Alien Species: A New Synthesis. Island Press, Washington/Covelo/London, pp. 1-15.

Musil, C.F., Midgley, G.F., 1990. The relative impact of invasive Australian acacias, fire and season on the soil chemical status of a sand plain lowland fynbos community. S. Afr. J. Bot. 56, 419-427.

Olsen, S.R., Sommer, L.E., 1982. Phosphorus. In: Page, A.L., Miller, R.H., Keeney, D.R. (Eds.), Methods of Soil Analysis. Part 2. Chemical and Microbiological Properties. American Society of Agronomy, Inc., Madison, Wisconsin, pp. 421-422.

Peperkorn, R., 2005. Schlüsselfaktoren der Invasivität von Acacia longifolia-experimentelle Untersuchungen im Vergleich zu Heimischen Arten Mediterraner Sandökosysteme. Ph.D. Thesis. University of Bielefeld, University of Bielefeld, Bielefeld, $117 \mathrm{pp}$.

Rey, A., Petsikos, C., Jarvis, P.G., Grace, J., 2005. Effect of temperature and moisture on rates of carbon mineralization in a Mediterranean oak forest soil under controlled and field conditions. Eur. J. Soil Sci. 56, 589-599.

Rogado, N.J., Batalha, J.F.C.S., Simões, J.J.M.F., Ribeiro, L.M., 1993. Esboço de uma Carta de Solos da Região de Aveiro na escala 1/100 000. Direcção Regional de Agricultura da Beira Litoral, Coimbra.

Roux, E.R., 1961. History of the introduction of Australian acacias on the Cape Flats. S. Afr. J. Sci. 57, 99-102.

Silva, R., 1977. Sector Fertilidade do Solo. Documentação 2, Laboratório Químico-Agrícola, Ministério da Agricultura e Pescas, Lisbon.

Sinsabaugh, R.L., Moorhead, D.L., 1994. Resource allocation to extracellular enzyme production-a model for nitrogen and phosphorus control of litter decomposition. Soil. Biol. Biochem. 26, 1305-1311.

Stock, W.D., Wienand, K.T., Baker, A.C., 1995. Impacts of invading $\mathrm{N}_{2}$-fixing Acacia species on patterns of nutrient cycling in two Cape ecosystems: evidence from soil incubation studies and ${ }^{15} \mathrm{~N}$ natural abundance values. Oecologia 101, 375-382.

Strayer, D.L., Eviner, V.T., Jeschke, J.M., Pace, M.L., 2006. Understanding the long-term effects of species invasions. Trends Ecol. Evol. 21, 645-651.

Vitousek, P.M., Walker, L.R., Whiteaker, L.D., Muellerdombois, D., Matson, P.A., 1987. Biological invasion by Myrica faya alters ecosystem development in Hawaii. Science 238, 802-804.

Wan, S.Q., Hui, D.F., Luo, Y.Q., 2001. Fire effects on nitrogen pools and dynamics in terrestrial ecosystems: a metaanalysis. Ecol. Appl. 11, 1349-1365.

Wardle, D.A., 1992. A comparative assessment of factors which influence microbial biomass carbon and nitrogen levels in soil. Biol. Rev. 67, 321-358.

Wardle, D.A., Bardgett, R.D., Klironomos, J.N., Setälä, H., van der Putten, W.H., Wall, D.H., 2004. Ecological linkages between aboveground and belowground biota. Science 304, 1629-1633.

Witkowski, E.T.F., 1991. Effects of invasive alien acacias on nutrient cycling in the coastal lowlands of the Cape Fynbos. J. Appl. Ecol. 28, 1-15.

Wolfe, B.E., Klironomos, J.N., 2005. Breaking new ground: soil communities and exotic plant invasion. BioScience 55, 477-487.

Yelenik, S.G., Stock, W.D., Richardson, D.M., 2004. Ecosystem level impacts of invasive Acacia saligna in the South African fynbos. Restor. Ecol. 12, 44-51.

Yelenik, S.G., Stock, W.D., Richardson, D.M., 2007. Functional group identity does not predict invader impacts: differential effects of nitrogen-fixing exotic plants on ecosystem function. Biol. Invasions 9, 117-125. 